\title{
Systems Biology-Based Study for Plant and Phytopathogen Interaction
}

\section{Guangyou Duan*}

European Molecular Biology Laboratory, Genome Biology Unit, Meyerhofstrasse 1, 69117 Heidelberg, Germany

With the advent of OMICs techniques, more and more OMICs data across different levels of biological molecular organization (such as the genome, transcriptome, proteome, or metabolome) have been generated $[1,2]$. It makes the study of biological system or the interaction between biological systems practical. As biotic stress for plants, the influence of phytopathogen including pathogenic bacteria or fungi on plants has attracted more and more attention [3] considering their economic damage on crop yields. From the view of systems biology, many studies have been designed for the interpretation and modelling of host-pathogen interactions [4] to understand pathogenic and defensive mechanisms, however most of the studies have focused predominately on the host or the pathogen part.

In [5], the metabolic interplay between five pairs of plants and phytopathogens was studied by constructing their genome-scale metabolic networks and the pathogen dependent impairment effects on the plants' metabolome was suggested. It provides insights into potential mechanisms of how phytopathogens exploit their host plants.

From the level of protein interaction, the interspecies proteinprotein interaction (PPI) network was constructed and exemplified in the study of Candida albicans-zebrafish interaction recently [6,7]. In their study, the simultaneously quantified time-course Candida albicans-zebrafish interaction transcriptomics and other OMICs data were used to reconstruct interspecies PPI network, and furthermore redox status was found critical in the battle between the host and pathogen. Other machine learning based computational methods were also designed to reconstruct the interspecies PPI between human T-cell leukemia viruses (HTLV) [8] or human immunodeficiency virus (HIV) $[9,10]$ and Human. The similar concept could also been applied in the study of plant-phytopathogen interaction.

With recent advances in sequencing technologies, especially nextgeneration sequencing (NGS), metagenome has been applied in the study of host-pathogen interaction [11,12] from the perspective of community. Proteome technique have also been applied to study the host-pathogen interaction, for example, in [13], the secretome and extracellular proteome of potato late blight pathogen Phytophthora infestans was profiled and provided insights into secretion mechanisms for oomycetes.

\section{References}

1. Augenlicht $L H$, Kobrin $D$ (1982) Cloning and screening of sequences expressed in a mouse colon tumor. Cancer Res 42: 1088-1093.

2. Lander ES, Linton LM, Birren B, Nusbaum C, Zody MC, et al. (2001) Initial sequencing and analysis of the human genome. Nature 409: 860-921.

3. De Vos M, Van Oosten VR, Van Poecke RM, Van Pelt JA, Pozo MJ, et al. (2005) Signal signature and transcriptome changes of Arabidopsis during pathogen and insect attack. Mol Plant Microbe Interact 18: 923-937.

4. Pritchard L, Birch $P$ (2011) A systems biology perspective on plant-microbe interactions: biochemical and structural targets of pathogen effectors. Plant Sci 180: 584-603.

5. Duan G, Christian N, Schwachtje J, Walther D, Ebenhöh O (2013) The Metabolic Interplay between Plants and Phytopathogens. Metabolites 3: 1-23.

6. Chao CC, Hsu PC, Jen CF, Chen IH, Wang CH, et al. (2010) Zebrafish as a model host for Candida albicans infection. Infect Immun 78: 2512-2521.

7. Wang YC, Lin C, Chuang MT, Hsieh WP, Lan CY, et al. (2013) Interspecies protein-protein interaction network construction for characterization of hostpathogen interactions: a Candida albicans-zebrafish interaction study. BMC Syst Biol 7: 79

8. Mei S, Zhu H (2014) Computational reconstruction of proteome-wide protein interaction networks between HTLV retroviruses and Homo sapiens. BMC Bioinformatics 15: 245

9. Qi Y, Tastan O, Carbonell JG, Klein-Seetharaman J, Weston J (2010) Semisupervised multi-task learning for predicting interactions between HIV-1 and human proteins. Bioinformatics 26: i645-652.

10. Kshirsagar M, Carbonell J, Klein-Seetharaman J (2013) Multitask learning for host-pathogen protein interactions. Bioinformatics 29: i217-226.

11. Schwartz S, Friedberg I, Ivanov IV, Davidson LA, Goldsby JS, et al. (2012) A metagenomic study of diet-dependent interaction between gut microbiota and host in infants reveals differences in immune response. Genome Biol 13: r32.

12. Nyyssönen M, Tran HM, Karaoz U, Weihe C, Hadi MZ, et al. (2013) Coupled high-throughput functional screening and next generation sequencing for identification of plant polymer decomposing enzymes in metagenomic libraries. Front Microbiol 4: 282.

13. Meijer HJ, Mancuso FM, Espadas G, Seidl MF, Chiva C, et al. (2014) Profiling the secretome and extracellular proteome of the potato late blight pathogen Phytophthora infestans. Mol Cell Proteomics 13: 2101-2113.
*Corresponding author: Guangyou Duan, European Molecular Biology Laboratory, Genome Biology Unit, Meyerhofstrasse 1, 69117 Heidelberg, Germany, Tel: +49-17632479083; E-mail: duan@embl.de

Received October 29, 2014; Accepted October 30, 2014; Published October 31 , 2014

Citation: Duan G (2014) Systems Biology-Based Study for Plant and Phytopathogen Interaction. J Plant Pathol Microb 4: e106. doi:10.4172/2157$7471.1000 \mathrm{e} 106$

Copyright: $\odot 2014$ Duan G. This is an open-access article distributed under the terms of the Creative Commons Attribution License, which permits unrestricted use, distribution, and reproduction in any medium, provided the original author and source are credited. 